\title{
A Case of Metastatic Renal Cell Carcinoma Invasion in External Auditory Canal
}

\author{
Yoon Ah Park, Tae Hoon Kong, Jae Woo Lee, and Sang Yoo Park \\ Department of Otorhinolaryngology-Head and Neck Surgery, Yonsei University Wonju College of Medicine, Wonju, Korea
}

\section{외이도를 침범한 전이성 신세포암 1 예}

박윤아 · 공태훈 · 이재우 · 박상유

연세대학교 원주의과대학 이비인후-두경부외과학교실

\author{
Received March 5, 2015 \\ Revised May 28, 2015 \\ Accepted June 16, 2015 \\ Address for correspondence \\ Sang Yoo Park, MD, PhD \\ Department of Otolaryngology- \\ Head and Neck Surgery, \\ Yonsei University Wonju \\ College of Medicine, \\ 20 Ilsan-ro, Wonju 26426, Korea \\ Tel $+82-33-741-0642$ \\ Fax $+82-33-732-8287$ \\ E-mail sangyoo3@yonsei.ac.kr
}

A renal cell carcinoma ( $\mathrm{RCC}$ ) is known for its high propensity for early metastasis. Among the metastatic cancers of the head and neck, RCC is the third most common disease after breast cancer and lung cancer. Head and neck metastasis of RCC occurs mainly in the thyroid gland $(36.6 \%)$, nose and sinus $(9.1 \%)$, and lesions in the ear canal and temporal bone are very rare. Although extremely rare, metastatic malignancy in the breast, lung, prostate, kidney to the external auditory canal have been reported in the literature. We report a case of metastatic RCC of the left external auditory canal in a 78-year-old male patient who had experienced multiple organ metastasis after nephrectomy due to renal cell carcinoma.

Korean J Otorhinolaryngol-Head Neck Surg 2015;58(10):717-21

Key Words External auditory canal $\cdot$ Metastasis $\cdot$ Renal cell carcinoma.

\section{서 론}

두경부에 발생하는 전이성 암의 경우 유방암과 폐암에 이 어 신세포암 순으로 발생하는 것으로 알려져 있으며 ${ }^{1)}$ 이 중 신세포암의 두경부 전이는 갑상선(36.6\%)과 비강 및 부비동 (9.1\%)에 주로 발생하고, 외이도 및 측두골에 발생하는 경우 는 매우 드물다. ${ }^{2)}$ 외이도에 발생하는 전이성 암은 매우 희박 하지만 유방암(29\%), 폐암(11\%), 전립선암(8\%), 미상(8\%), 신장 (6\%) 등의 순으로 보고되었다. ${ }^{3)}$ 국내 문헌에는 신세포암이 이 하선, 비강 및 부비동, 구강저, 갑상선, 악하선에 전이된 경우 가 간혹 보고된 바가 있으나 외이도 및 측두골에 전이된 증 례는 아직 보고되지 않았으며, 국외 문헌의 경우도 매우 드 물어 외이도 및 측두골 전이는 6예가 보고되었을 뿐이다. ${ }^{2-7)}$ 저자들은 과거 신세포암으로 근치적 신장 적출술을 받은 후 다발성 장기 전이로 치료 중인 78세 남자 환자에서 좌측 외이 도에도 원격 전이가 발생한 증례를 경험하였기에 문헌고찰과 함께 보고하고자 한다.

\section{증 례}

78세 남자 환자가 좌측 귀의 청력 감소, 이통, 이충만감 및 이 루를 주소로 내원하였다. 과거력상 환자는 8년 전 우측 신장의 신세포암(renal cell carcinoma, Clear cell type, T3bNOMO, Stage III)을 진단받고 우측 근치적 신장 적출술(radical nephrectomy)을 시행받았으며 이후 4년 뒤 이자머리(head of pancreas) 부위의 전이가 발견되어 날문보존이자샘창자 절제 술(pylorus-preserving pancreaticoduodenectomy)을 시행 받았고, 내원 9개월 전 폐의 다발성 전이가 발견되어 tyrosine kinase 억제제(pazopanib, $800 \mathrm{mg} /$ 일)를 복용 중이었으며 tyrosine kinase 복용 후 신세포암에 대한 반응 평가는 이루 어지지 않은 상태였다. 이학적 검사상 좌측 외이도 골부에 위 치하여 외이도를 막고 있는 약 $0.5 \times 0.5 \mathrm{~cm}$ 크기의 폴립(polyp) 모양의 동통을 동반한 분홍색 종물이 관찰되었으며 점액성 이루가 동반되었다(Fig. 1). 순음청력검사에서는 좌측의 기도 청력 $50 \mathrm{~dB}$, 기도-골도차 $15 \mathrm{~dB}$ 의 혼합성 난청 소견이 관찰 
되었다(Fig. 2), 측두골 전산화단층촬영상 외이도 하벽의 골 파괴 소견과 함께 연조직 음영이 외이도를 채우고 있었고, 고막 은 분간이 어려웠으며, 중이강과 유양동 일부까지 연조직 음 영이 확대된 양상으로 이소골의 이상 소견은 없었다(Fig. 3).

종물은 출혈성 경향이 높았으며 환자가 통증을 심하게 호소 하며 협조가 잘 되지 않아 전신마취 하에 후이개 절개를 통한 외이도 종물 절제 생검술을 계획하였다. 수술 중 동결 절편 조 직검사(frozen biopsy)상 신세포암으로 보고되었으며 종양의 경계는 명확하고 주변 조직 및 고실로의 침범 소견은 없었다.

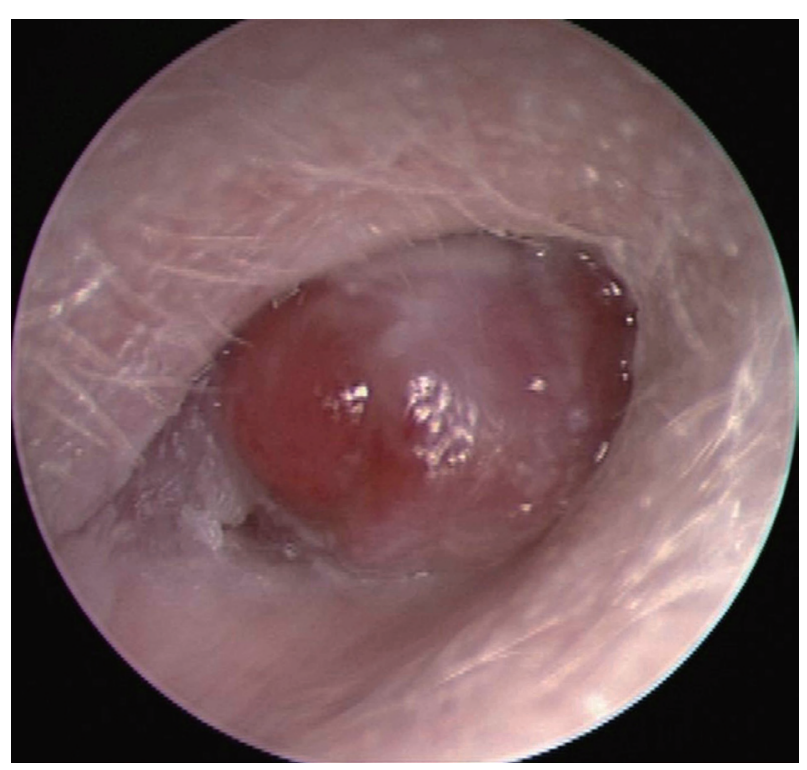

Fig. 1. The endoscopic finding of the left external auditory canal. Reddish pink colored polypoid soft tissue mass is totally obstructing external auditory canal. Serous discharge is combined.
환자가 고령이고 신세포암의 과거력이 있으며 다발성 장기 전 이로 치료 중임을 감안할 때 신세포암의 외이도 전이에 대한 근치적 수술(lateral temporal bone resecton)의 필요성은 없 다고 사료되었으며 환자는 외래에서 이충만감 및 지속적인 이 루를 호소하였고 전산화단층촬영에서 중이강 내 연조직 음영 이 관찰되었기에 고실탐색술을 시행하였다. 중이강과 유양동 은 종양이 아닌 염증성 육아조직으로 가득 차 있어 단순 유양 동 절제술 및 고실성형술을 시행하였다. 수술 소견 상 외이도 종괴의 기원은 외이도 후하벽 결손부위에서 유래된 것으로 보 이며, 이 부위에 유착되어 있었고, 고막은 이상소견이 없어 외 이도에 국한된 신세포암으로 사료되었다.

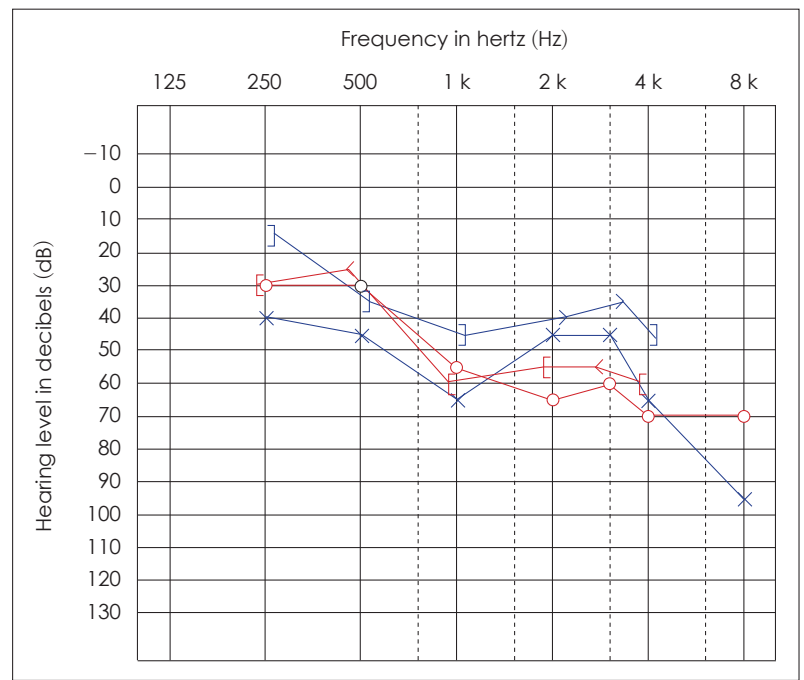

Fig. 2. Pure tone audiogram. The audiogram shows the air-bone gap (15 dB) of the left ear (red-right ear, blue-left ear).

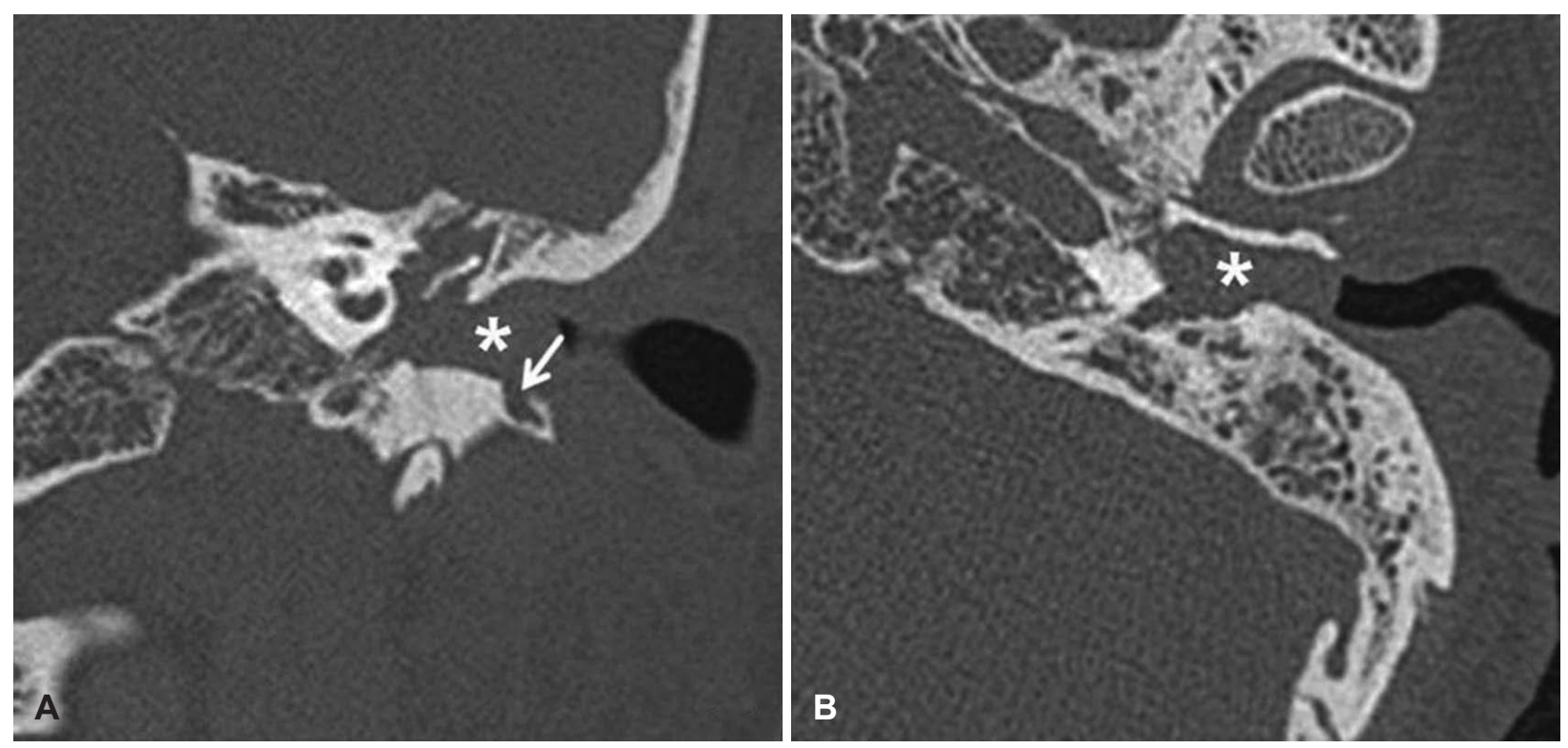

Fig. 3. Temporal bone computed tomography. Axial view (A), coronal view (B): soft tissue shadow is found at mastoid air cell, middle ear cavity and external auditory canal (afterisk). At external auditory canal, soft tissue shadow is found with bone defects of inferior wall (arrow). 
병리학적 소견상 외이도의 종물은 육안적으로 $1.0 \times 0.7 \times$ $0.5 \mathrm{~cm}$ 크기였고, 현미경 소견에서 점막 하 조직 내에 투명한 세포질을 갖는 상피양 종양세포가 군집을 이루면서 증식, 침 윤하고 있었다(Fig. 4A). 종양세포는 세포질이 투명하고 세포 막이 뚜렷하였으며 핵의 이형증은 심하지 않았다(Fig. 4B). 면역조직화학염색에서 종양세포는 pan-cytokeratin, CD10에 양성이었으며, chromogranin A, synaptophysin, S-100 protein 에는 음성 소견을 보여 전이성 신세포암종으로 확진할 수 있 었다(Fig. $4 \mathrm{C}$ and D). 중이강 및 고막, 유양동의 연조직은 염 증성 육아조직으로 진단되었다.

환자는 수술 직후 종양내과로 의뢰되었으며 지속적으로 tyrosine kinase 억제제를 복용하며 추적 관찰하였다. 수술 4개월째 외이도 전벽 골부에서 분홍색의 돌출된 종물이 관 찰되었으며 재발소견으로 사료되어 종양내과에 재의뢰하여 지속적으로 치료 중이다(Fig. 5).
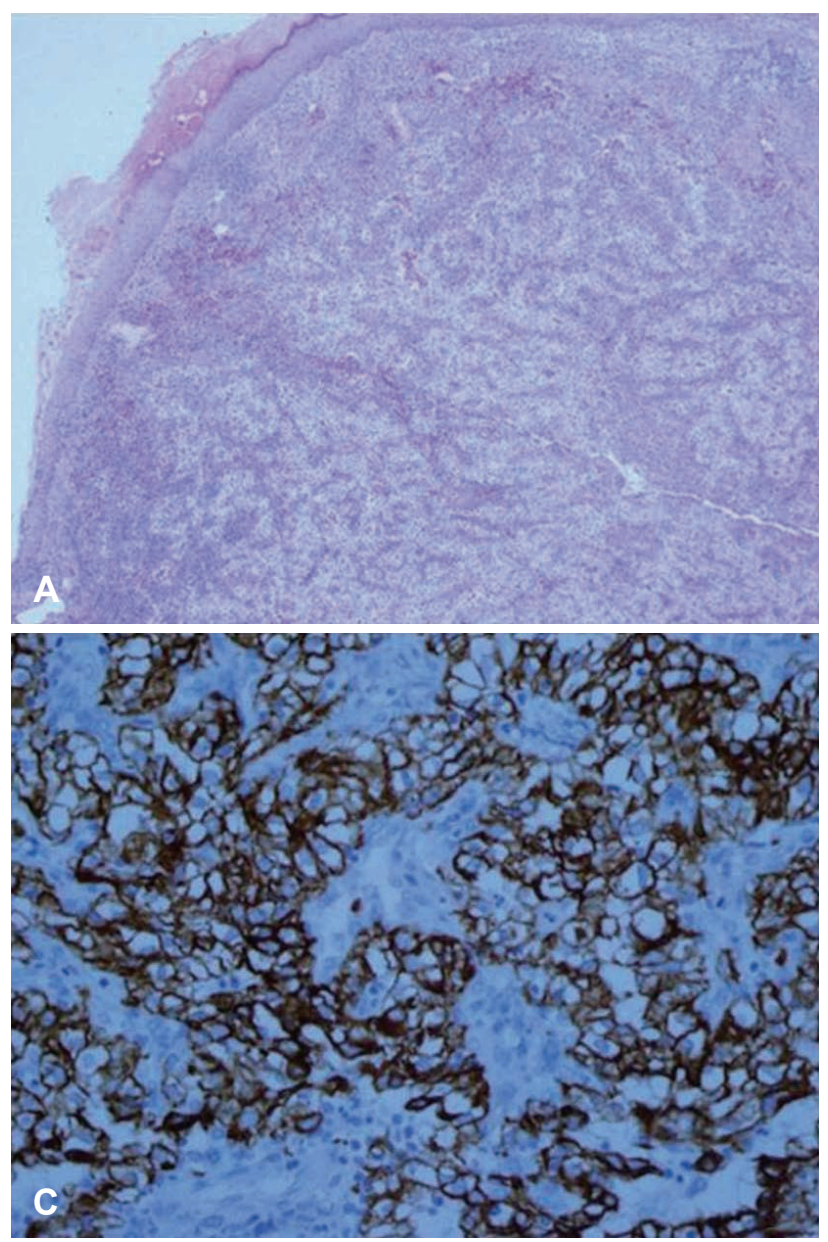

\section{고 찰}

신세포암은 악성종양 중 약 2 3\%를 차지하며, 남성에서 여 성보다 약 2 배 정도 많이 발생하지만 초기 증상이 없어 진단 이 늦어지는 경우가 많다. 진단 당시에 이미 25 30\%에서 전 이성 병변을 함께 보이며 원발부위의 치료 후 수년에서 수십 년이 지난 후에도 원격전이가 일어난다. ${ }^{8)}$ 신세포암의 두경부 로의 전이는 드문 것으로 알려져 있으며, 신세포암의 약 $16 \%$ 에서 두경부 전이가 보고되고 있으나, 이들 중 $8 \%$ 만이 증상을 보이는 것으로 알려져 있다. ${ }^{5)}$

신세포암의 두경부 전이경로에 대해서는 크게 두 가지 이론 이 주로 알려져 있는데 하나는 대정맥 경로로서 악성세포가 하대정맥을 통하여 우심장, 폐, 좌심장을 거쳐 상악동맥으로 전이된다는 이론으로서 신세포암이 복강, 폐 전이를 거쳐 두 경부에 전이되는 경로로 설명된다. ${ }^{9)}$ 다른 하나는 척수정맥총 경로로서 악성세포가 Baston 정맥총을 통하여 두개내 정맥

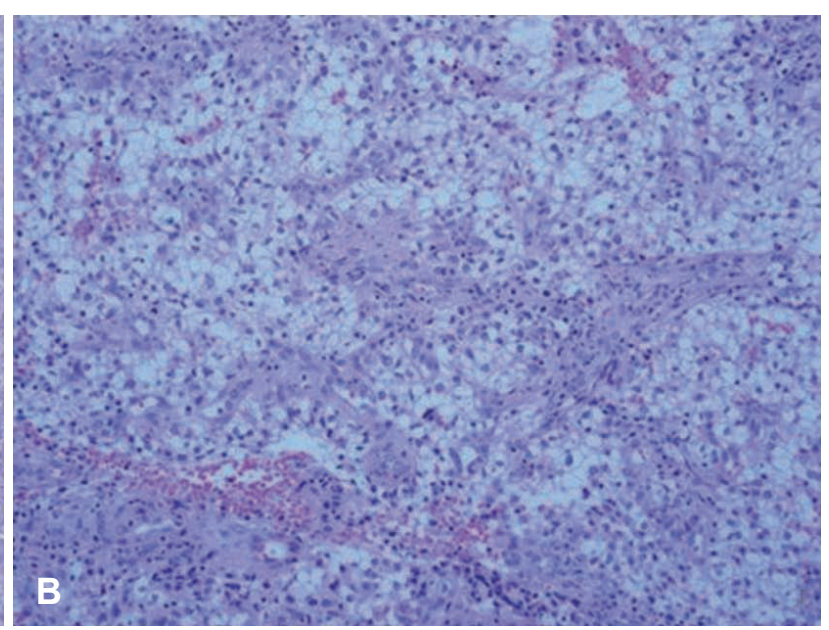

Fig. 4. Microscopic findings. Epithelioid tumor cells with clear cytoplasm proliferate and infiltrate in submucosa $(H \& E \times 40)(A)$. The tumor cells have not severe dysplasia of the nucleus and have clear cell membrane and cytoplasm (H\&E $\times 400)(B)$. Immunohistochemical staining, tumor cells were positive for pan-cytokeratin $(H \& E \times 400)(C)$. Immunohistochemical staining, tumor cells were positive for CD10 $(H \& E \times 400)(D)$. 


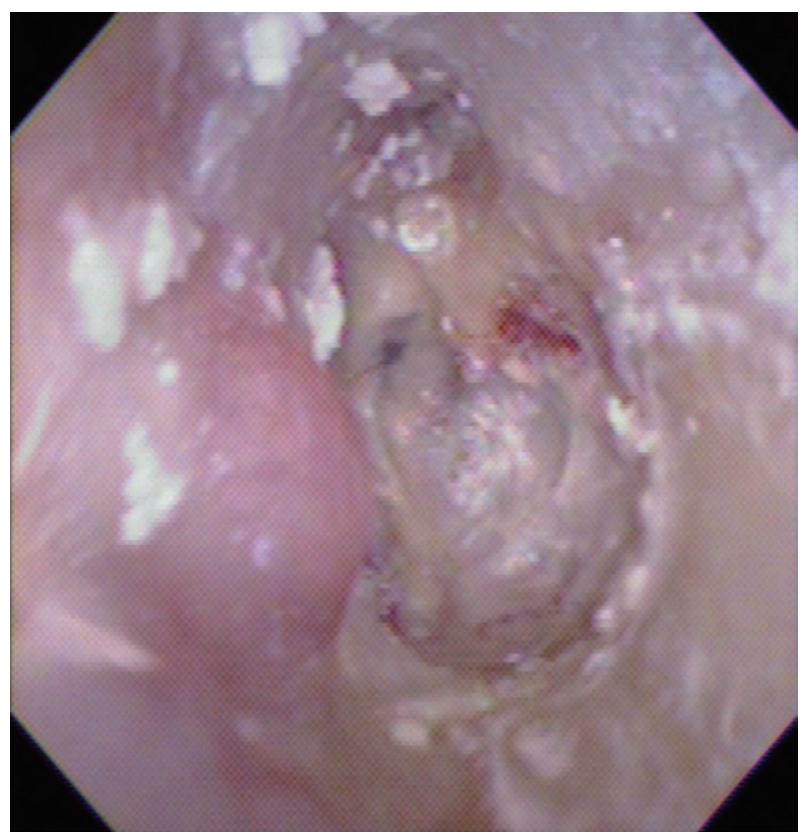

Fig. 5. The endoscopic finding of the left external auditory canal, 4 months after surgery. A reddish pink colored protruding soft tissue mass is observed again on anterior bony wall of external auditory canal wall.

총, 해면상 정맥총을 거쳐 두경부로 전이된다는 이론으로 이 는 신세포암이 폐순환을 거치지 않고 두경부 영역으로의 단 발성 원발전이를 일으키는 배경이 된다. ${ }^{10)}$ 본 증례에서는 이전 이자와 폐에 전이가 있은 후 외이도로의 전이가 발생한 것으로 보아 위의 두 경로 중 대정맥 경로로 전이된 것으로 사료된다.

신세포암의 외이도나 측두골로의 전이는 매우 드물다. 국 내에는 아직 보고된 바 없고 해외에 6예가 보고되어 있다. 그 중 2예는 신세포암의 과거력 없이 청력 감소, 박동성 이명, 이 충만감 등의 이과적 증상을 주소로 내원하여 외이도 조직검 사에서 전이성 신세포암이 발견되어 원발부위 진단이 이루 어진 경우이며, ${ }^{3,6}$ 다른 4 예는 과거에 신세포암으로 신적출술 을 시행받고 2 8년 후 외이도 및 측두골에서 전이성 신세포 암이 발견된 경우이다. 2,4,57) 이들 중에는 외이도 종물로 나타 나지 않고서 측두골에 전이된 사례가 있었으며,") 외이도 종물 로 나타났으나 측두골까지 침범한 사례도 보고되었다.4) 본 증 례에서는 신세포암으로 신적출술을 시행받고 이후 다발성 장 기 전이로 수술적 치료와 약물 치료를 하던 중 외이도에서 전이가 발견된 사례이다. 또한 환자는 과거 만성 중이염 기왕 력이 없던 환자로 외이도 종양의 크기 증가 및 환경 악화로 염증이 조장되어 중이염 소견을 동반한 형태로 나타난 것으 로 추정되었다.

신세포암이 외이도에 전이된 경우 치료방법에 대해서는 아 직 명확히 규정되지 않았다. 전이성 신세포암의 경우 단발성 전이를 보이며 절제가 가능한 경우라면 광범위한 수술적 절제
가 권고되며 수술적 절제가 불가능한 경우에는 방사선 치료 및 항암화학요법, 면역 치료, 호르몬 치료 등을 할 수 있다. ${ }^{11)}$ 방사선 치료의 경우 신세포암의 일차 치료로는 추천되지 않 지만 두경부 영역으로 전이된 환자에게서 증상 감소에 도움이 되는 것으로 알려져 있으며 항암화학요법, interferon-alpha (IFN- $\alpha$ ), interleukin-2(IL-2), lymphocyte activated killer 세 포 등의 면역 치료, 호르몬 치료는 잘 반응하지 않는 것으로 알려져 있다. ${ }^{12}$ 최근에는 tyrosine kinase 억제제인 sunitinib 이 IFN- $\alpha, \mathrm{IL}-2$ 보다 생존기간을 유의하게 증가시킨다는 것 이 보고되었다. ${ }^{13)}$ 현재까지 보고된 외이도 및 측두골 전이 사 례에서는 수술적 치료 없이 방사선 치료와 호르몬 요법을 사 용한 사례 1예, 광범위 절제술 후 고식적 방사선 치료를 한 사 례 1예, 방사선 치료와 면역 치료를 병행한 사례 1예가 보고 되었으나 치료에 잘 반응하지 않았다. ${ }^{34,7)}$ 나머지는 치료방법과 예후에 대해 명확히 보고된 바가 없다. ${ }^{25,6)}$

본 증례에서는 환자가 심한 통증을 호소하며 협조가 잘 되 지 않아 환자 동의하에 전신마취하 절제 생검술을 시행하였 으며 동결 절편 조직검사상 신세포암으로 보고되었다. 종양이 외이도에 국한되고 다발성 전이로 치료받고 있었기 때문에 외 측 측두골 절제술(lateral temporal bone resection) 같은 외 이도 및 측두골에 대한 광범위 절제술은 시행하지 않았고, 중이염에 대해 단순 유양동 절제술만 시행하였다. 문헌고찰을 고려하였을 때 본 환자의 경우에는 외래에서 조직검사를 먼 저 시행해보거나, 혹은 협조가 어려운 경우 전신마취하 생검술 시행 후 동결절편 조직검사에서 신세포암이 보고되면 수술 을 종료하는 것이 일반적인 것으로 생각하며, 환자가 호소하 였던 지속적인 이루에 대해서는 항생제 치료를 먼저 하는 것 이 바람직하였을 것으로 사료된다. 항생제 치료에도 불구하 고 이루가 지속될 시에는 청력 보존과 중이염 합병증을 예방 하기 위해 단순유양동 절제술을 시행할 수 있을 것이다.

신세포암의 평균 5 년 생존율은 $45 \%$ 이나 원격전이가 있는 경우 5년 생존율은 $5 \%$ 이하로 좋지 않다. ${ }^{14)}$ 두경부 영역으로 전이된 경우 평균 생존기 간이 7 개월에 지나지 않았으며, ${ }^{15)}$ 외 이도 및 측두골에 전이된 사례에서도 평균적으로 10 개월의 생존 기간을 보였다. ${ }^{34)}$ 특히, 방사선 치료와 호르몬 요법을 병 행하였던 증례에서 치료 3 개월 뒤 외이도에 국소 재발소견을 보였는데 ${ }^{4}$ 본 증례에서는 수술적 치료 후 4 개월 뒤 외이도에 재발소견을 보였다는 점에서 유사한 사례로 사료된다.

신세포암의 외이도 전이 시 난청, 이통, 이루 등의 비특이적 증상을 보이며 신체검진, 영상의학적 소견에서도 특징적 소견 을 보이지 않아 다른 종물과 감별하기 어렵다. 신세포암은 전 이를 잘 하는 특성이 있으며 원발부위의 치료 후 수년에서 수 십년이 지난 후에도 원격전이가 일어날 수 있다. 특히 외이도 
및 측두골 전이 시 치료 후에도 조기에 국소 재발할 수 있고, 예후가 좋지 않음을 고려할 때 신중한 치료 전 평가 및 적극 적인 치료가 필요할 것으로 사료되며, 효과적인 치료방법을 위한 연구가 추가적으로 수행되어야 할 것이다.

\section{REFERENCES}

1) Hill BA, Kohut RI. Metastatic adenocarcinoma of the temporal bone. Arch Otolaryngol 1976;102(9):568-71.

2) Ferron P, LeClerc J. [Metastasis of a hypernephrome to the ear]. J Otolaryngol 1982;11(4):235-8.

3) Ingelaere PP, Simpson RH, Garth RJ. Metastatic renal cell carcinoma presenting as an aural polyp. J Laryngol Otol 1997;111(11):1066-8.

4) Zirul ED, Steinbaum FL, West G, Matthews AJ. Metastatic renal cell carcinoma presenting as a tumor of the external auditory canal. J Am Osteopath Assoc 1983;83(3):255-7.

5) Goldman NC, Hutchison RE, Goldman MS. Metastatic renal cell carcinoma of the external auditory canal. Otolaryngol Head Neck Surg 1992;106(4):410-1.

6) Michaelson PG, Lowry TR. Metastatic renal cell carcinoma presenting in the external auditory canal. Otolaryngol Head Neck Surg 2005;
133(6):979-80.

7) De Vos C, Gerard JM, Decat M, Gersdorff M. Metastatic renal cell carcinoma to the temporal bone: case report. B-ENT 2005;1(1):43-6.

8) Motzer RJ, Bander NH, Nanus DM. Renal-cell carcinoma. N Eng1 J Med 1996;335(12):865-75.

9) Nahum AM, Bailey BJ. Malignant tumors metastatic to the paranasal sinuses: case report and review of the literature. Laryngoscope 1963; 73:942-53.

10) Gottlieb MD, Roland JT Jr. Paradoxical spread of renal cell carcinoma to the head and neck. Laryngoscope 1998;108(9):1301-5.

11) Woo HJ, Bai CH, Song SY, Kim YD. Metastatic renal cell carcinoma in the nasal cavity and mouth floor. Korean J OtorhinolaryngolHead Neck Surg 2008;51(4):380-3.

12) Miyamoto R, Helmus C. Hypernephroma metastatic to the head and neck. Laryngoscope 1973;83(6):898-905.

13) Motzer RJ, Hutson TE, Tomczak P, Michaelson MD, Bukowski RM, Rixe O, et al. Sunitinib versus interferon alfa in metastatic renal-cell carcinoma. N Engl J Med 2007;356(2):115-24.

14) Holland JF, Bast RC, Morton DL, Frei E, Kufe DW, Weichselbaum RR. Cancer medicine. 3rd ed. Philadelphia: Lea \& Febiger;1993. p.1529-38.

15) Park YW, Hlivko TJ. Parotid gland metastasis from renal cell carcinoma. Laryngoscope 2002;112(3):453-6. 